\title{
The Evolution of CSR: An Integrated Approach*
}

\author{
Fabrizio Mosca**, Chiara Civera ${ }^{* * *}$
}

\begin{abstract}
Corporate social responsibility (CSR) has been traditionally interpreted as the sum of practices, policies, and strategies linked with social and environmental benefits that corporations implement to serve multiple stakeholders' interests simultaneously. The evolution of meanings and implications of traditional and contemporary interpretations of CSR, focuses on integrated CSR as a breakthrough approach to business, society, and environment. Several theories and trends that integrated CSR is rooted in are: stakeholder theory, ethics, value creation, and the increasing global call for sustainable growth and development, under both financial and ethical perspectives. Selected case studies will serve as empirical evidence of processes, practices, and strategic tools that can allow the integration of CSR into the company core business and will open avenues for further discussions and practical innovative developments in CSR strategy to both academics and practitioners.
\end{abstract}

Keywords: Corporate Social Responsibility; Sustainability; Global Markets; Integrated CSR; Integrated Management; Corporate Governance

\section{Integrated Corporate Social Responsibility Approaches}

In the past three decades, stakeholders' growing interests and more complex globalised business phenomena and relationships have pushed the development and integration of socially responsible practices within business organisations in various global and local industries as well as geographical contexts and business sizes (Brondoni, 2003, 2014; Jamali et al., 2009; Mosca \& Civera, 2017; O'Riordan \& Fairbrass, 2008; Surroca et al., 2013; Waddock et al., 2002).

Scholars have extensively underlined different paradigms and interpretations of what is commonly called corporate social responsibility (CSR), together with the different roles that CSR has played over time (Carroll, 2008; Dahlsrud, 2008; Visser, 2010, 2012).

However, the huge amount of academic research and institutional work (e.g., from the European Commission and the World Business Council for Sustainable Development) has not converged into a common and conclusive definition of what constitutes CSR (Mosca \& Civera, 2017; Russell et al., 2016; 2017; Taneja et al.,

\footnotetext{
* The authors: F. Mosca $§ 1,3$, C. Civera $§ 2,4,5$

** Associate professor of management, University of Turin (fabrizio.mosca@unito.it)

*** Lecturer of Management, University of Turin (chiara.civera@unito.it)
} 
2011), leaving the CSR debate open as to how, why, and through which labels companies approach CSR. Diverging views about CSR meanings and possible applications have emerged over time, from more sceptical ones that see CSR as a distortion of companies' economic purpose (Friedman, 1970; Murray, 2005) to more utopic ones that picture business organisations as taking part in the world's social development (Rudolph, 2005). For better clarity and understanding, all the diverging views can be typically grouped into two main perspectives. On the one hand, a stream of scholars includes CSR among the instrumental and utilitarian strategies or strategic activities that create competitive advantage and improve companies' reputation and brand awareness among customers through communication (Alcaniz et al., 2010; Castaldo et al., 2009; Hur et al., 2014; Lantos, 2001; Luo \& Bhattacharya, 2006; Porter \& Kramer, 2006; Sen \& Bhattacharya, 2001; Singh, 2016; Walsh et al., 2003). This residual CSR approach (Freeman et al., 2010) has been extensively criticised for being static and representing an achievement rather than an innovative and flexible process for continuous improvement (De Colle et al., 2014), to the point that CSR as such seems to have failed in its intent (Visser, 2012). On the other hand, CSR might be intended as a way to make business organisations core and active social and sustainable partners. As partners, they can cooperate to achieve the three main streams of sustainability (social, environmental, and economic) simultaneously and strive for balance even if contradictory logics (e.g., social and economic) can create conflicts within the organisation and among its stakeholders (Carroll, 1979, 1991; Crane et al., 2014; De Colle \& Gonella, 2003; Freeman \& Phillips, 2002; Freeman et al., 2010; Jamali \& Mirshak, 2007; Perrini, 2005; Visser, 2012).

According to Freeman et al. (2010), this view opens avenues for more integrated approaches to CSR, which they conceptualised as the "integration of social, ethical, and environmental concerns into the management criteria for corporate strategy" (p. 259). Integrated CSR is therefore pursued together with core business goals as a redefinition of priorities and responsibilities (Post et al., 2002). In this regard, stakeholder theory (Freeman, 1984) comes across as a fundamental theoretical framework to add value to the CSR theory and its practical applications; it also represents a pillar for explaining integration at multiple levels within the business organisation and throughout the supply chain.

Since its formal postulation in the book Stakeholder Theory: The State of the Art in 2010, integrated CSR has been widely defined in the management literature as the integration of CSR into different aspects of business by emphasising management systems and governance that favour the implementation of an adequate and coherent CSR strategy (Salvioni \& Astori, 2013; Salvioni \& Bosetti, 2014; Vitolla et al., 2016, 2017). CSR integration has also been considered from the accounting point of view through studies explaining the contents and impacts of integrated reporting systems that aim at combining social and financial impacts (as required by European laws and national applications of such laws; Garcia-Sanchez \& Noguera-Gàmez, 2017; Sierra-Garcia et al., 2015). Contemporary studies have also addressed the issue of CSR integration along the supply chain (Yawar \& Seuring, 2017; Apolloni et al., 2013). They also viewed integrated value creation as a result of coherent responses to stakeholders' expectations, appropriate management systems for CSR, and value chain linkages (Visser \& Kymal, 2015). With the term integration, a broader spectrum of opportunities and challenges arise for the management to effectively 
implement CSR. Integrated CSR - which, in the vision of Freeman et al. (2010), takes a step forward compared to the mere integration of CSR into business activities - defines an approach to CSR that should involve the whole company and its suppliers, customers, and stakeholders. Hence, the broader implications of an integrated CSR approach call for further empirical and theoretical investigations to clarify the logic and provide a set of managerial implications for practitioners.

Accordingly, the aim of this conceptual paper is to shed light on integrated CSR as an approach by 1) exploring the antecedents and discussing the evolutions and characterisations of residual versus integrated CSR approaches; 2) drawing a framework that can support the clarification of integrated CSR meanings and dimensions by exploring tools, actions, processes, and policies for integrated CSR; and 3) identifying some business cases where traces of such an approach are found in both strategic postures and actions.

\section{Strategic and Historical Evolution of CSR}

Some of the earliest traces of the implementation of socially responsible practices can be found in the middle 1800s with the advent of the Industrial Revolution, when companies were first realising the social impacts that their everyday business activities would have on minors, workers' household spending, female work, and working conditions in general. During these years, welfare policies were implemented by companies for their internal stakeholders (mainly in the United Kingdom), and philanthropy, as a practice towards external stakeholders in need, was undertaken by wealthy entrepreneurs (Carroll, 2008; Visser, 2010). Although such social concerns have been embraced since the first forms of more evolved enterprises were created, it was only in the 1950s that CSR formally entered the business lexicon, when the firm became a component of social equilibrium (Brondoni, 2014). In 1953, Bowen defined CSR as a set of compulsory rules that both managers and company owners must respect when pursuing policies, making decisions, or drawing strategic actions that are consistent with the expectations and values that permeate society. His view of CSR reflects the awareness that companies could no longer ignore the great impact of business on citizens and communities; it strengthened the CSR debate in the years to come, both in the American and European landscapes.

The 1960s marked an important period in the evolution of CSR. The first environmental movements were born out of political and social public fronts fighting against the exploitation of natural resources (Visser, 2010). Companies were thought to play a central role in environmental and social disputes, as shown by the definitions of CSR during this decade. Accordingly, Davis (1960) talked about the "iron law of responsibility," stating that avoiding taking responsibility would eventually lead companies to lose their social power, which is why entrepreneurs should design actions and make decisions that partially go beyond mere economic interests. In the same year, Frederick introduced concern for human resources and societal economic conditions to the CSR concept, confirming that companies' resources should be directed to social purposes as well. While great steps forward in CSR conceptualisation and strategic relevance were made during these years, it was not until the 1970s that concrete CSR programmes within companies began focusing on different activities rather than just philanthropy (Muirhead, 1999). 
In 1971, Harold Johnson postulated the various interests-economic, social, environmental, and employees' well-being - that a company should consider when making strategic decisions. In the same decade, the contents and applications of CSR grabbed the attention of institutions and the regulation of companies' conduct began, with CSR definitions put forth by the Committee for Economic Development (1971) and formal codes of CSR designed by big global companies (e.g., the Sullivan Principles at General Motors in 1971; Visser, 2010). With the proliferation of theories supporting CSR as a philosophy guiding managerial decision making through economic, legal, ethical, and discretional responsibility (Carroll, 1979), the debate around the very real responsibility of businesses arose and further developed in the 1980s.

In particular, shareholder theory (Friedman, 1970) and stakeholder theory (Freeman, 1984) counterpose shares to stakes as forms of responsibility, supporting two opposite views. Balancing the interests of various categories of stakeholders (from customers to suppliers) is the theoretical root from which contemporary CSR logics evolve. Serving a plurality of interests guides the company in its journey towards sustainable development, which is defined as meeting "the needs and aspirations of present generations without compromising the ability to meet those of future" (Bruntland Commission, 1987).

From this decade onwards, the strategic and ethical importance of people directly and indirectly connected to and involved in the company's activities became the principle driving CSR conceptualisations, consistent with the corporate citizenship argument, which promotes a corporate role that aims to improve the impact of companies' actions and behaviours on society (Carroll, 2008).

As a natural strategic development of CSR, the late 80s and the 90s represent the ages of scholars contributing to enrich CSR of managerial implications and advancing its institutionalisation.

Various concepts that matched and strengthened CSR emerged: community partnerships (Smith, 1997); corporate reputation based on the achievement and communication of sustainable performance (Donaldson \& Preston, 1995); CSR impacts on financial and social performance (Griffin \& Mahon, 1997; Harrison \& Freeman, 1999); and strategic philanthropy based on advanced tools such as sponsorships, partnerships, cause-related marketing, and employee volunteerism rather than mere cash donations (Muirhead, 1999). Moreover, in 1994, John Elkington's Triple Bottom Line principles shaped the future expansion of CSR practices that contribute to economic, social, and environmental value creation. Within such a framework of value creation, a process of stronger CSR institutionalisation began with international and national certification bodies establishing the most well-known standards, such as International Organization for Standardization (ISO) 9000 and 14000 (quality and environmental certifications, respectively), ISO 26000 (guidance standard for social responsibility), Global Reporting Initiative guidelines for sustainability reporting, SA8000 (for workers' conditions in the supply chain), and AA1000 (for social and ethical accounting, auditing, and reporting).

The proliferation of standards and norms contributed to making CSR a more pragmatic approach in the business context. This process reached its peak during the past two decades. In the 2000s, CSR gathered momentum within academia and among practitioners. Moreover, the contemporary contextual market conditions- 
which see globalisation, financial and environmental crises, and information and communication technologies (ICTs) transforming stakeholders' expectations, competition, and companies' innovative approaches to the market at a rapid pace (Brondoni, 2003, 2014; Perrini \& Tencati, 2008; Tanahashi, 2010)-shape new tactics to responsibility and sustainability, making it more of a strategic decision to redefine products, services, and business models (Kuepfer \& Papula, 2010). The growing concern for sustainable development pervades all global markets and industries (Risso, 2012; Salvioni \& Bosetti, 2014). The 17 Sustainable Development Goals by the United Nations (2015) are the expression of a global common agenda aiming at reducing poverty, protecting the planet, and ensuring prosperity for all. Firms as global citizens must directly participate in this process, which is why CSR has undergone several evolutions as a strategy and an approach. In 2001, the European Commission considered CSR a voluntary integration of social and environmental concerns into business activities. In 2011, the European Commission policy emphasised the almost compulsory integration of such concerns into business operations, with the aim of maximising companies' social impact. The same transformations were reflected in the reporting system. While the disclosure of social and environmental information through the Social Report was a standalone and not a compulsory activity in the early 2000s, in 2014, as a starting point, a European Commission (2014, p. 95) directive made the disclosure of non-financial and diversity information compulsory for larger companies and groups with an average of 500 employees. Such a reporting system influences the integration of financial and non-financial information as a means for more comprehensive communication at different stakeholder levels. EU member states have applied these laws since January 2017.

\section{Review of Contemporary Scholarship: Antecedents and Features of Residual and Integrated CSR Approaches}

As shown by the quick review of the historical and strategic evolutions of CSR, a variety of approaches to sustainability and responsibility characterise the CSR landscape. CSR is therefore thought of as a multidimensional concept. Contemporary CSR scholarship has discussed some of the CSR failures coming from a CSR residual logic (Freeman et al., 2010) and highlighted the separation from an integrated logic, contributing to clarifying the latter approach.

One of the harshest criticisms about the classical notion of CSR came from Visser (2012), who supported the idea that CSR has failed. He made a distinction between CSR 1.0 (modern, marginal CSR) and CSR 2.0 (systemic corporate sustainability and responsibility), using the advent and influence of ICTs and social media as a metaphor for the changes and pressures on companies. The main differences between these two approaches can be considered peculiar to the residual versus integrated logics of CSR. In particular, CSR 1.0 is defined as 1) peripheral, which is typical of mainly the largest companies; 2) incremental, based on a quality management model that favours incremental improvements but does not match the urgency of social and environmental issues; and 3) uneconomical, as there is no certainty that the market will reward, at least in the short term, sustainable and responsible companies (Visser, 2012). By contrast, CSR 2.0 reflects a systemic CSR that uses business models and 
products to generate positive changes in society. As a more integrated conception, it suggests an approach based on collaboration, stakeholder orientation, and performance, which will be ultimately rewarded by market incentive systems. The typical CSR undertaken by large Western companies is therefore replaced by an approach that companies of any size worldwide can embrace. This is evident from a supply chain perspective. Supply chain integrity is one of the pillars of CSR 2.0, according to which the empowerment of small suppliers and/or producers in developing countries can contribute to making the whole supply chain more resilient from a social and business perspective. Company size is crucial in the CSR debate; Freeman and Velamuri (2006) proposed a new definition of CSR as company stakeholder responsibility to assert that responsibility must be enacted in all the relationships established with stakeholders (at any level) in a logic of collaboration (Crane et al., 2014) and should be transversal to organisations of any size (companies as well as corporations).

The diversification of activities under systemic CSR or CSR 2.0 pushes companies to go beyond the typical dimensions defining traditional and residual views of CSR. Traditional philanthropy (e.g., unplanned cash donations), for instance, is naturally replaced by a more strategic approach (Porter \& Kramer, 2002), where the social cause of interest is connected to the core business of the company, or by the development of new forms of businesses and collaboration such as social enterprises, integrating social and economic objectives. The strategic commitment of leadership to sustainability and responsibility can guarantee the effectiveness of CSR practices. According to this approach, Gorenak and Bobek (2010) discussed total responsibility management, which surpasses the simple "doing well" by doing good (Byus et al., 2010; Karnani, 2011; Meyer, 2015), as is typical of philanthropic actions and leaders detached from social matters, to set up processes and business models that are responsible and sustainable at their core. Furthermore, the implementation of standards and norms, which has strongly characterised CSR design by large companies since the early 2000s, is no longer the most effective form of CSR. De Colle et al. (2014) directed an extensive and constructive conceptual and methodological criticism at CSR standards, including their limitations in meeting wider stakeholder interests (Rasche \& Esser, 2006). First, in spite of some positive effects deriving from standards adoption, such as improved reputation, CSR standards might lead to companies losing ownership and responsibility of the processes they are implementing, as well as creating constraints from the many rules that might impede further ethical choices and favour constant improvements. Second, being a managerial-centred process, CSR might transform into a mere compliance activity rather than a proactive motivation to progress (Jamali \& Mirshak, 2007; Visser, 2012). Third, CSR standards implementation as a standalone approach can lead to the misassumption that only by adopting a standard can companies create positive outcomes.

\subsection{Antecedents of Residual and Integrated CSR}

Based on a systematic literature review of the criticisms directed at traditional CSR approaches, theoretical papers, and empirical research on CSR integration, conceptual characterisations of residual and integrated approaches are hereby framed and discussed. 
Some factors represent antecedents for different approaches to be forged. Contextual conditions - which can be represented by geography and political/institutional environments (Abreu et al., 2005; Campbell, 2007) - as well as companies' original attitudes (e.g., mission and values) and strategic postures (companies' approach to external stakeholders and changes) explain much about how CSR logic is pursued. As summarised in Table 1, Matten and Moon (2008) referred to explicit and implicit CSR as contextual institutional models that favour the development of more residual and more integrated CSR approaches, respectively. In the explicit model, corporate governance is more oriented to short-term decision making, and the institutional context is detached from the implementation of social and sustainable practices (Campbell, 2007). Therefore, whatever companies decide to undertake about CSR does not find limitations neither a fertile ground in the reference environment. By contrast, in the implicit model, the governance system favours long-term decision making, and local institutions, which consider cooperation a catalyst for sustainable and responsible outcomes, enable the system to create a network with all stakeholders. Institutional influences affect both the attitude and the posture that a company creates and strategically develops towards its stakeholders and the social environment. Companies that "do well" by being good corporate citizens will be more likely to adopt a cooperative strategic posture and strive for innovation in a transformative and flexible manner (Carroll, 1991; Crane et al., 2014; Moon et al., 2005; Soundararajan et al., 2016; Strand \& Freeman, 2015; Visser, 2012) compared to companies that are just required to "do well" by doing good in a competitive yet static way (De Colle et al., 2014; Visser, 2012). For the latter, attitudes and strategic posture lead to their considering CSR as a mere competitive advantage, confirming the residual nature of such logic.

\subsection{Features of Residual and Integrated CSR}

Freeman et al. (2010) proposed a comprehensive framework of residual and integrated CSR that characterised each in terms of selected variables: CSR definition, stakeholder focus, economic focus, CSR purpose, CSR business model, processes, and activities. The integrated CSR approach is profoundly rooted in stakeholder theory. It is therefore oriented to stakeholder engagement to create value for the overall success of the organisation against a logic of mere profit redistribution that uses CSR simply to sustain the legitimacy of the business. Stakeholder management differs greatly between the two approaches. Berman et al. (1999) defined strategic stakeholder management as an instrumental concern for stakeholders in order to improve financial performance; this is attributed to a residual CSR logic. By contrast, intrinsic stakeholder commitment is the normative (or moral) commitment to advance stakeholder interests that can benefit both strategy and financial performance; hence, it is a more integrated view. In this case, stakeholders at any level, through joint interests and collaboration, can become active partners of the company and reach sustainable goals together (Brondoni, 2003, 2014; Crane et al., 2014; Soundararajan et al., 2016; Strand \& Freeman, 2015; Visser, 2012).

Based on the criticisms examined earlier, the way that companies interact and deal with social and environmental issues through their actions greatly differs between the approaches. Luetkenhorst (2004) and Jamali and Mirshak (2007) supported the idea that the residual (more instrumental) view interprets CSR as a compliance tool 
that strives for harm minimisation through rhetoric behaviour (Campbell, 2007). Using the rhetoric of social responsibility means making extensive use of CSR communication, with a narrative based on promises and claims for convincing rather than proving (Fassin \& Buelens, 2011; Hur et al., 2014). On the contrary, engagement in social and environmental matters through substantive actions, beyond legal compliance (Campbell, 2007; Lambin, 2009; Perrini \& Vurro, 2014), means adopting performance-driven CSR communication based on experiences and storytelling, which outlines tangible benefits rather than promises (Du et al., 2010; Pomering \& Dolnicar, 2009).

Consequently, the two divergent approaches result in opposite CSR outcomes. On the one hand, residual logics converge to add a social role to products and servicesthat is, maintaining the same products/services offered by simply annexing a certain sustainable characteristic (e.g., respecting an environmental process within production or delivery) that can facilitate the attainment of a standard around that particular element of the product/service.

On the other hand, integrated CSR represents a redefinition of business models and responsibilities that involves all business functions and extends beyond companies' boundaries to the whole supply chain. Integrating CSR from the upper end to the bottom of the value chain means being able to more effectively identify waste and better determine stakeholders' expectations, as well as establish joint decisionmaking processes with stakeholders in a more resilient supply chain. Furthermore, integrating CSR into the core firms' business implies the redesign of products and services so that they become sustainable and responsible at their core-outputs that integrate social values and actions (integrated outputs). This includes raw material sourcing, waste elimination in the transformation process, fair and equal economic contracts with suppliers, technical characteristics of transformed products and their packaging, governance of processes and relationships, and the promotion of ethical consumption (Casalegno \& Civera, 2016; Visser, 2012).

Table 1 summarises the main features of integrated versus residual CSR approaches.

Table 1: Antecedents and Features of Residual and Integrated CSR 


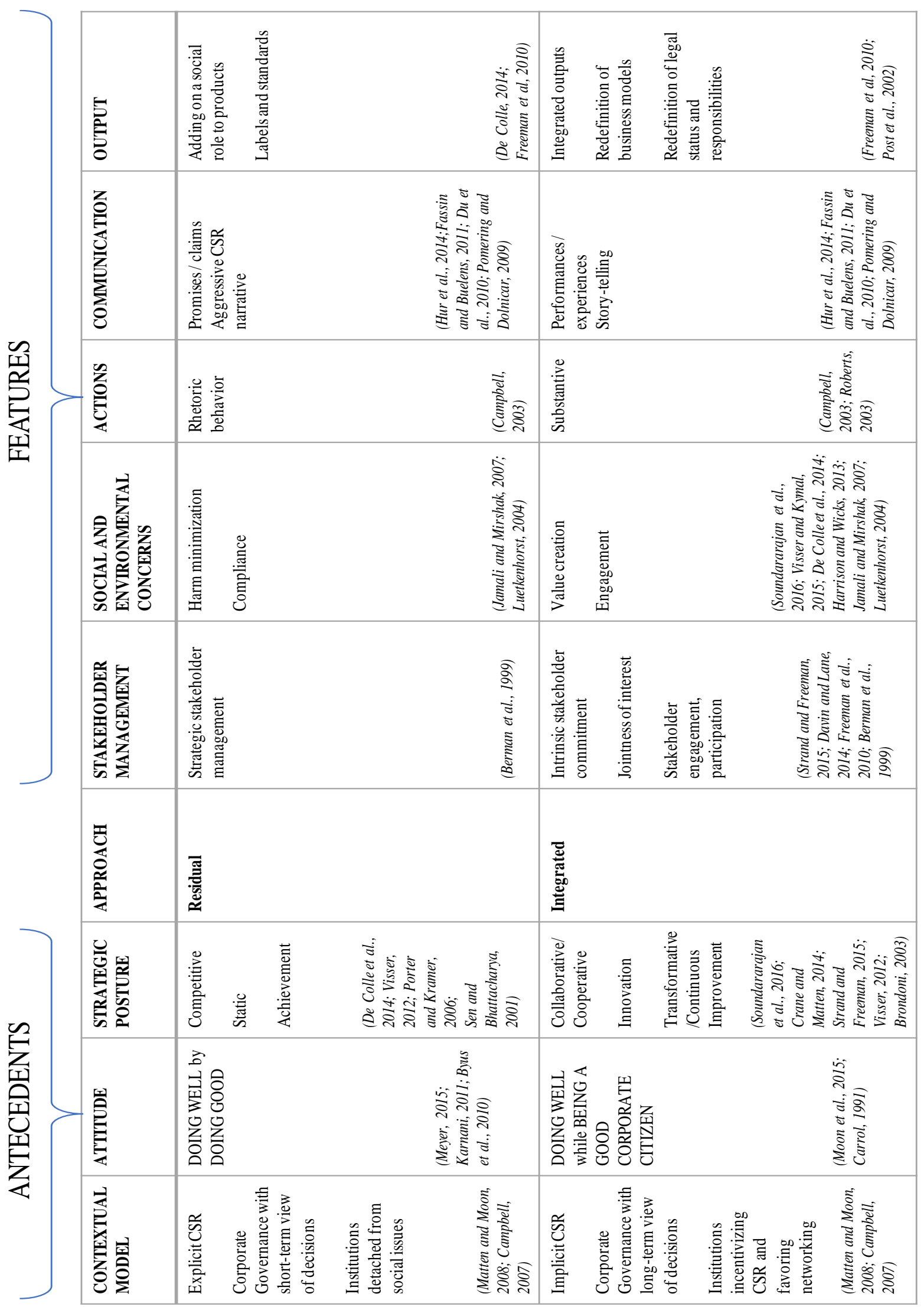




\section{Integrated CSR Framework: From Theory to Practice}

This section aims to practically structure integrated CSR into a set of tools, activities, and actions that are reported in the "Framework of Integrated CSR" (Figure 1).

The framework is the result of ongoing literature reviews and empirical evidence on CSR conceptualisations and implementation that the authors have conducted and collected in the past two years. Earlier versions of the framework have been published in the authors' previous works (Casalegno \& Civera, 2016; Mosca et al., 2016). In the present paper, contents and meanings are strengthened-after theoretically clarifying the boundaries of residual and integrated approaches - and further tested through other case studies.

\section{Figure 1: Framework of Integrated CSR}

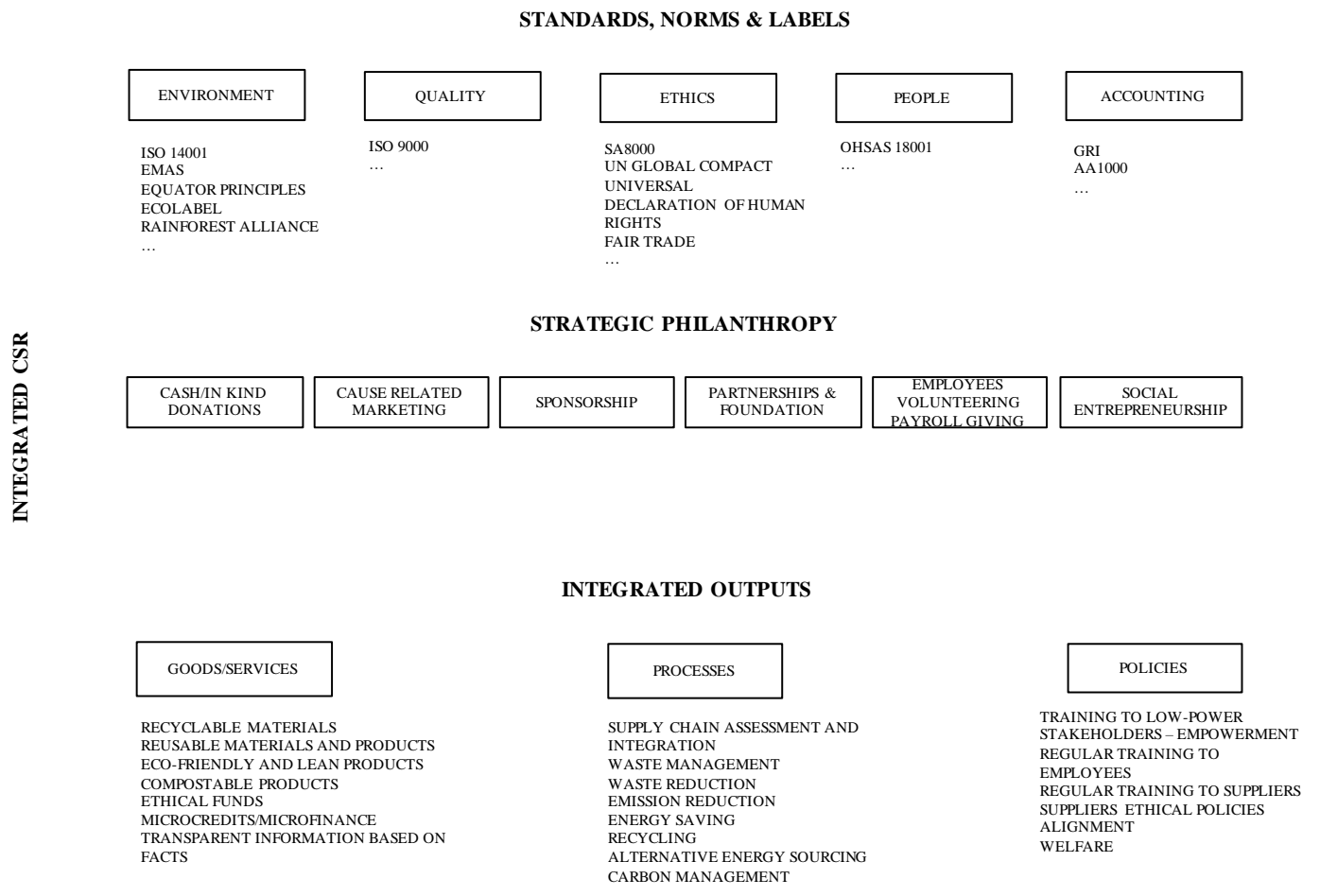

As illustrated in Figure 1, the integrated CSR framework is composed of three main dimensions, ranging from evidence of a more residual approach to a more integrated one (as indicated by the arrow): 1) standards, norms, and labels; 2) strategic philanthropy; and 3) integrated outputs.

The first dimension includes all the national and international sets of standards, norms, and labels that a firm can implement for the environment (e.g., ISO 14001), quality (e.g., ISO 9001), ethics (e.g., SA8000 on ethical standards), people (mainly for employees; e.g., OHSAS18001 on work health and safety), and accounting (e.g., AA1000 standard for accountability). Despite being voluntary in its implementation, this dimension is no longer an element of differentiation in the CSR landscape and has become a sort of bare minimum for firms that want to compete at a global level 
according to certain reputational criteria. In addition, if implemented as a standalone approach, standards, norms, and labels do not say much about the integration of CSR into the company's core business and remain a residual tool serving the scope of communication, stating a circumscribed achievement rather than a repositioning of business models.

The second dimension marks a step forward in the integrated CSR approach and includes all the activities and actions undertaken in the strategic philanthropy area. To be more accurate, the term "strategic" applied to this field underlines a philanthropic approach that is linked and consistent with the core business of the company (Porter \& Kramer, 2002). The main tools at companies' disposal to implement strategic philanthropy are cash or in-kind donations, cause-related marketing (a more commercial-oriented practice through which firms support a social cause of their interest by co-branding their products with the non-government organisations [NGOs] pursuing the social cause), sponsorships (in the field of art, sport, culture, and education), partnerships with third-sector organisations around planned projects, establishing the company's own foundation to facilitate project implementation, employee volunteerism and payroll giving, and social entrepreneurship as a hybrid organisational form to conduct further economic activities with a stronger social and/or environmental purpose. The more these activities are related to and consistent with the company's core business, the more the CSR approach can be considered integrated.

Barilla Group, an Italian food company established in 1877, undertakes an integrated CSR approach based on the three main streams of sustainability: people (customers), communities, and the planet. "Good for you, good for the planet" is the claim guiding Barilla on its path to meeting the United Nations Sustainable Development Goals. Based on a strong commitment to communities, Barilla's philanthropic activities are consistent with its core business; the company provides in-kind donations (pasta and food) that meet the needs of populations in a state of emergency. A group of Barilla's volunteers (called the Barilla Angels) actively operate side by side with NGOs; when this is not possible, Barilla supports the cause through stronger partnerships with NGOs. The company is also strongly involved in fighting food waste and donates excess food through a coordination mechanism with local associations devoted to food placement to poor people (Banco Alimentare in Italy or Feeding America in the United States).

$\square$ Through the Michele Ferrero Entrepreneurial Projects, the Ferrero Group - the Italian leader in chocolate confectionery-aims at "safeguarding the health, educational and social development of children and teenagers in the local communities where they operate." The philanthropic initiative consists of the establishment and development of social enterprises (in the form of production plants) in Cameroon, South Africa, and India, aiming to create jobs for lowpower populations in emerging countries and promote the educational and social growth of children under the wider 
philanthropic project named "United Kinder of the World." These activities are strategically connected to the Ferrero core business in that they contribute to more effective and efficient sourcing and production (economic advantages) as well as the sustainable social development of local populations through empowerment and a strong logic of joint decision making and cooperation. As stated on the company's website, The "Dedicated Social Fund" set up within the local branches of the group participating in the Michele Ferrero Entrepreneurial Project is accrued each year with additional funding, which represents a percentage of the value of the estimated annual production volumes of the plant; such funds are thus allocated regardless of whether the branch itself has generated any profit.

$\square$ Through the Coca-Cola Foundation (started in 1984), the CocaCola company carries out international philanthropic actions consistent with the company's core business. The focus on water, a core element of Coca-Cola production, is one example. In 2016, more than 300,000 dollars were donated to the Alternative Indigenous Development Foundation, Inc., for the Agos Ram Pump Project to facilitate access to water in seven communities in the Philippines using ram pump technology. Furthermore, to guarantee favourable environmental conditions for rivers to flow properly and to source water more safely, a project in cooperation with American Rivers was founded for the removal of a dam on the Patapsco River in Maryland. Another project in Indonesia in partnership with Atma Jaya Catholic University of Indonesia involved more than 120,000 dollars for building green subsidised apartments through rainwater harvesting, establishing a waste bank, and implementing community-based education programmes.

The third dimension is the greatest expression of the integration of CSR into companies' core business. Aside from the integration of ethical and social values into companies' mission and vision - which has been evident in most large companies in the last few years - integrated outputs represent a further concrete integration of social, ethical, and environmental practices into products/services, processes, and policies. This means, for instance, a reconfiguration of materials used for production that allow recycling; reusing through circular economy logics (Mosca et al., 2015) and zero-waste outputs; a revolution of systems of dialogue with stakeholders that include cooperative decision making; a new approach to the supply chain that seeks opportunities for partnerships throughout the chain to create value; the establishment of programmes and policies aimed at promoting stakeholders' engagement by empowering them and increasing their autonomy, especially in long and complex supply chains involving low-power stakeholders that are also critical resource providers for the company (Pfeffer \& Salancik, 2003); and the configuration of processes that implement, among other practices, energy saving through alternative sources, waste management, and water reuse. 
The chief executive officer of Vodafone, one of the world's leading telecommunication groups, states:

Our products and services play a central role in the daily lives and livelihoods of more than half a billion people across 26 countries, bringing about a revolution in access to education, healthcare and financial services. Our approach to sustainable business ensures we are committed to aligning our business goals with societal benefits in order for our work to deliver positive social outcomes, not just commercial and financial success.

The integration of Vodafone's CSR actions into their core business is evident in most of its strategies. In the 2016 Sustainability Report, the company described what can be defined as an integrated output in intent and configuration:

Our ambition is to expand the benefits of mobile to a greater number of women at all levels of society through a range of targeted commercial programmes. ... More than 2 billion people globally still do not have access to banking facilities. The majority of them are women. This makes it difficult to manage household finances, save or run a business. There is therefore both a social need and a business opportunity in improving women's access to financial services.

That is why a decade ago, Vodafone and Safaricom (a Kenyan associate) developed the first mobile money transfer service, called $M$ Pesa (which is easy to use, cheaper, and convenient), as a means of empowerment for low-power stakeholders to improve their autonomy and control over financial affairs and ultimately increase their business capacity and livelihood.

Carlsberg Group, the Danish beer brewer founded in 1847, makes commitments around products, processes, and policies that aim at guaranteeing zero carbon footprint, zero water waste, zero irresponsible drinking, and a zero-accident culture. One of the company's most remarkable integrated outputs is the green fibre bottle that Martin Pedersen, CEO of EcoXPac-the Danish packaging company and main partner of Carlsberg in the development of this product-described as both truly sustainable and appealing to consumers. According to Pedersen, "The coming three years will be both challenging and exciting, and we can't wait to put the bottle on the market." The fully biodegradable bottle will be an expression of a sustainable innovation that considers waste and improvements throughout the whole supply chain by employing stronger life-cycle assessment:

Its fibres will come from responsibly managed sources, with trees replanted at the same rate that they are harvested, or even faster. Furthermore, any potential impact from using fibres will be included in the environmental assessments. And while the bottle will degrade into environmentally non-harmful materials if discarded randomly, the intention is that it will form part of a proper waste management system, just like today's bottles and cans. 
The collaboration between Carlsberg and the packaging company represents a valuable partnership that underlines the "importance of a circular economy for sustainable growth." Carlsberg's commitment to a circular economy and its cooperative strategic posture allow for a wider base of stakeholders to become the company's partners. The creation of a Carlsberg circular community encourages innovators and sustainability-oriented actors to cooperate on various sustainable projects, mainly those involving products and processes.

$\square$ Stella McCartney is a brand for young Londoners founded in the early 2000s. Its commitment to sustainability and responsibility is a core part of the brand's values and ethos and is evident in all its business activities, from its responsible sourcing to its environmentally friendly stores and offices. The company's commitment to ethical trade is certified by its membership in the Ethical Trading Initiative, an alliance of organisations of various natures to improve working conditions around the world. The main pillars characterising Stella McCartney's CSR strategy relate to the product configuration, choice of materials, and integration of activities throughout the supply chain: avoiding the use of leather, fur, or skin; avoiding animal testing; and refraining from the use of PVC material, angora rabbits, and sand-blasting techniques that might harm both consumers and workers. In Stella's words,

It's really the job of fashion designers now to turn things on their head in a different way, and not just try to turn a dress on its head every season. Try and ask questions about how you make that dress, where you make that dress, what materials you're using. I think that's far more interesting, actually. I think that the way to create sustainable fashion is to keep asking these questions while making sure to make desirable, luxurious, beautiful clothing and accessories that women want to buy.

\section{Conclusions and Emerging Issues}

This study aimed to clarify the complexity of CSR by identifying different approaches within which companies can undertake CSR actions and design CSR projects. By outlining the historical and strategic evolutions that CSR has witnessed over time, this paper helped shed light on two main CSR approaches: residual and integrated. Based on an extensive literature review, the authors proposed a taxonomy of the antecedents and features of residual and integrated CSR approaches, highlighting the shift of contemporary CSR practices towards the latter logic. The study showed that the many criticisms around traditional CSR conceptualisations all push and converge towards more integrated CSR practices. In highlighting the peculiarities of an integrated CSR approach, extensive references to stakeholder theory were made and supported the identification of integrated CSR dimensions. Standards and norms, strategic philanthropy, and integrated outputs emerged as the main categories within which CSR is made explicit, varying from the bare minimum (adoption of standards as a standalone approach) to the maximum expression of integration (products, processes, and policies that are sustainable themselves). The 
description of some business cases of CSR integration contributed to clarifying the concept of integration in a practical manner and enriching the framework of integrated CSR (first proposed by the authors in other works) with further activities.

Understanding the dynamics of integrated CSR means acknowledging a series of challenges that emerge for companies. First, the complexity resulting from the adoption of a multi-stakeholder logic that aims at building partnerships and collaboration through the supply chain requires ad hoc strategies and people appointed to this task. That is why CSR has increasingly become a strategic function within business organisations that needs to be integrated into all the other functions to create the economic, social, and environmental value that companies seek to obtain and spread. Second, integrated CSR is an approach that is relevant to companies of any size; this represents an avenue for further implementation and start-up business creation intrinsically based on such an approach. Third, integration is pursued inside the company by integrated management approaches and transparent governance systems, among others. This is no longer considered a managerial-centred perspective; instead, it is the activation of a systematic dialogue and interaction between managers of all business functions, employees at all levels, and shareholders. At the same time, integration extends outside the company as an engagement process that involves all groups of stakeholders and contributes to a shift from a company-stakeholder logic to a company-partner logic. The challenge is for firms to establish a more valuable dialogue and joint decision making for stakeholders to equally and fairly satisfy their expectations, which will result in more efficient and effective product/service configuration, more ethical decisions, and more transparent access to key information from both sides. Working on CSR integration throughout the supply chain is a key issue for truly and coherently embracing integrated CSR as a business model redesign and a form of company repositioning. This is also one of the ways to contribute to cost savings and create a real impact on companies' efficiency and reputation. The extent to which this can increase firms' profits and lead to a better reward from the market is an interesting avenue for further investigation that the authors have been discussing for a long time (Visser, 2012). Through this study, we hope to have highlighted that it is worth understanding how a business is conducted and how money is made rather than focusing the CSR debate on what companies do with the money they create.

\section{Bibliography}

Abreu, R., David, F., \& Crowther, D. (2005). Corporate social responsibility in Portugal: empirical evidence of corporate behaviour. Corporate Governance: The international journal of business in society, 5(5), 3-18.

\section{https://doi.org/10.1108/14720700510630013}

Alcañiz, E. B., Cáceres, R. C., \& Pérez, R. C. (2010). Alliances between brands and social causes: The influence of company credibility on social responsibility image. Journal of business ethics, 96(2), 169-186.

https://doi.org/10.1007/s10551-010-0461-X

Appolloni, A., Risso, M., \& Zhang, T. (2013). Collaborative Approach for Sustainable Auditing of

Global Supply Chains. Symphonya. Emerging Issues in Management, 2, 19-31.

https://doi.org/10.4468/2013.2.02appolloni.risso.zhang

Berman, S. L., Wicks, A. C., Kotha, S., \& Jones, T. M. (1999). Does stakeholder orientation matter? 
The relationship between stakeholder management models and firm financial performance. Academy of Management journal, 42(5), 488-506.

https://doi.org/doi:10.2307/256972

Brondoni, S. M. (2014). Global Capitalism and Sustainable Growth. From Global Products to

Network Globalisation. Symphonya. Emerging Issues in Management, 1, 10-31.

http://dx.doi.org/10.4468/2014.1.02brondoni

Brondoni Silvio M. (2003) Network Culture, Performance \& Corporate Responsibility, Symphonya.

Emerging Issues in Management (symphonya.unimib.it), 1, 8-24.

http://dx.doi.org/10.4468/2003.1.02brondoni

Bruntland, G.H. (1987), “Our Common Future”, United Nations World Commission on Environment and Development (Bruntland Commission), Oxford

Byus, K., Deis, D., \& Ouyang, B. (2010). Doing well by doing good: Corporate social responsibility and profitability. SAM Advanced Management Journal, 75(1), 44.

Campbell, J. L. (2007). Why would corporations behave in socially responsible ways? An institutional theory of corporate social responsibility. Academy of management Review, 32(3), 946967.

http://dx.doi.org/10.2307/20159343

Carroll, A.B. (2008), A History of Corporate Social Responsibility, Concepts and Practices. In Andrew Crane, Dirk Matten, Abgail McWilliams, Jeremy Moon, Donald S. Siegel (ed.) The Oxford Handbook of Corporate Social Responsibility, OUP Oxford. https://doi.org/10.1093/oxfordhb/9780199211593.001.0001

Carroll A.B. (1991), "The Pyramid of Corporate Social Responsibility: Toward the Moral Management of Organizational Stakeholders", Business Horizons, 34, July-Aug, pp. 39-48. http://doi.org/10.1016/0007-6813(91)90005-G

Carroll A.B. (1979), "A Three-Dimensional Conceptual Model of Corporate Social Performance", Academy of Management Review, 4, pp. 497-505.

https://doi.org/10.5465/AMR.1979.4498296

Casalegno, C. \& Civera, C. (2016) “Impresa e CSR: La «Non comunicazione» di successo. Regole per una gestione responsabile delle relazioni". Increase, Franco Angeli

Castaldo, S., Perrini, F., Misani, N., \& Tencati, A. (2009). The missing link between corporate social responsibility and consumer trust: The case of fair trade products. Journal of business ethics, 84(1), $1-15$.

https://doi.org/10.1007/s10551-008-9669-4

CED (Committee for Economic Development), (1971), Social Responsibilities of Business Corporations. New York: CED

Crane, A., Palazzo, G., Spence, L. J., \&Matten, D. (2014). Contesting the value of "creating shared value". California management review, 56(2), 130-153. https://doi.org/10.1525/cmr.2014.56.2.130

Dahlsrud A. (2008), "How Corporate Social Responsibility is Defined: an Analysis of 37

Definitions", Corporate Social Responsibility and Environmental Management, 15, pp. 1-13. https://doi.org/10.1002/csr.132

Davis K. (1960), “Can Business Afford to Ignore Social Responsibilities?” California Management Review, 2, pp. 70-76. https://doi.org/10.2307/41166246

de Colle, S., Henriques, A., \& Sarasvathy, S. (2014). The paradox of corporate social responsibility standards. Journal of Business Ethics, 125(2), 177-191.

https://doi.org/10.1007/s10551-013-1912-y

de Colle Simone, Gonella Claudia (2003), Corporate social responsibility: the need for an integrated 
management framework. International Journal of Business Performance Management, vol. 5, n. 23, pp. 199-212 https://doi.org/10.1504/IJBPM.2003.003254

Donaldson, T., \& Preston, L. E. (1995). The stakeholder theory of the corporation: Concepts, evidence, and implications. Academy of management Review, 20(1), 65-91. https://doi.org/10.5465/AMR.1995.9503271992

Du, S., Bhattacharya, C. B., \& Sen, S. (2010). Maximizing business returns to corporate social responsibility (CSR): The role of CSR communication. International Journal of Management Reviews, 12(1), 8-19. https://doi.org/10.1111/j.1468-2370.2009.00276.x

European Commission (2011), "Communication from the Commission to the European Parliament, the Council, the European Economic and Social Committee and The Committee of the Regions", Bruxelles, 681 final COM

European Commission (2001), "Promoting an European Framework for Corporate Social Responsibility”, Green Paper and COM 366, Brussels

Fassin, Y., \&Buelens, M. (2011). The hypocrisy-sincerity continuum in corporate communication and decision making: A model of corporate social responsibility and business ethics practices. Management Decision, 49(4), 586-600. https://doi.org/10.1108/00251741111126503

Frederick W.C. (1960), "The Growing Concern over Business Responsibility", California Management Review, 2, 54-61. https://doi.org/10.2307/41165405

Freeman R. E., Wicks A., Harrison J., Parmar B., S. de Colle (2010), Stakeholder Theory: The State of The Art, Cambridge University Press. http://doi.org/10.1080/19416520.2010.495581

Freeman, R. E., \& Velamuri, S. R. (2006). A new approach to CSR: Company stakeholder responsibility. In Corporate social responsibility (pp. 9-23). Palgrave Macmillan UK.

Freeman R.E., Phillips R.A. (2002), "Stakeholder Theory: a Libertarian Defence” Business Ethics Quarterly, 12, n. 3, pp. 333

Freeman R.E. (1984), Strategic Management: A Stakeholder Approach, Boston: Pitman

Friedman M. (1970), The Social Responsibility of Firms is to Increase its Profits, New York Times Magazine.

https://doi.org/10.1007/978-3-540-70818-6_14

García-Sánchez, I. M., \& Noguera-Gámez, L. (2017). Integrated Reporting and Stakeholder Engagement: The Effect on Information Asymmetry. Corporate Social Responsibility and Environmental Management. 24, 395-413.

https://doi.org/10.1002/csr.1415

Gorenak S., Bobek V. (2010), "Total responsibility management indicators and sustainable development", International Journal of Sustainable Society, Vol. 2, n.3.

Griffin, J. J., \& Mahon, J. F. (1997). The corporate social performance and corporate financial performance debate: Twenty-five years of incomparable research. Business \& society, 36(1), 5-31. https://ssrn.com/abstract=2267176

Harrison J.S, Freeman R.E. (1999), "Stakeholders, Social Responsibility, and Performance: Empirical Evidence and Theoretical Perspectives", Academy of Management Journal, Oct., pp. 479485. https://doi.org//10.2307/256971

Hur W.M, Kim H., Woo J. (2014), "How CSR Leads to Corporate Brand Equity: Mediating 
Mechanisms of Corporate Brand Credibility and Reputation”, Journal of Business Ethics, vol. 125, 1. pp. $75-86$

Jamali, D., \& Mirshak, R. (2007). Corporate social responsibility (CSR): Theory and practice in a developing country context. Journal of business ethics, 72(3), 243-262.

https://doi.org/10.1007/s10551-006-9168-4

Jamali, D., Zanhour, M., \& Keshishian, T. (2009). Peculiar strengths and relational attributes of SMEs in the context of CSR. Journal of Business Ethics, 87(3), 355-377.

https://doi.org/10.1007/s10551-008-9925-7

Johnson, H. L. (1971), Business in contemporary society: Framework and issues. Wadsworth Pub. Co..

Karnani, A. (2011), "Doing well by doing good": The grand illusion. California Management Review, 53(2), 69-86. https://doi.org/10.1525/cmr.2011.53.2.69

Kuepfer J., Papula J. (2010), “Corporate Social Responsibility - the Dilemmas Behind the Popular

Concept and How to Best Address Them", International Journal of Sustainable Society, vol. 2, n.3

Lambin, J.J. (2009). Capitalism and Sustainable Development. Symphonya. Emerging Issues in

Management (www.unimib.it/symphonya), 2, 3-9.

http://dx.doi.org/10.4468/2009.2.02lambin

Lantos, G. P. (2001). The boundaries of strategic corporate social responsibility. Journal of consumer marketing, 18(7), 595-632.

https://doi.org/10.1108/07363760110410281

Luo, X., \& Bhattacharya, C. B. (2006). Corporate social responsibility, customer satisfaction, and market value. Journal of marketing, 70(4), 1-18.

https://doi.org/10.1509/jmkg.70.4.1

Luetkenhorst, W. (2004). Corporate social responsibility and the development agenda.

Intereconomics, 39(3), 157-166.

https://doi.org/10.1007/BF02933583

Matten, D., \& Moon, J. (2008). "Implicit" and "explicit" CSR: A conceptual framework for a comparative understanding of corporate social responsibility. Academy of management Review, 33(2), 404-424.

http://dx.doi.org/10.2307/20159405

Meyer, M. (2015). Positive business: doing good and doing well. Business Ethics: A European Review, 24(S2).

https://doi.org/10.1111/beer.12105

Moon, J., Crane, A., \& Matten, D. (2005). Can corporations be citizens? Corporate citizenship as a metaphor for business participation in society. Business Ethics Quarterly, 15(3), 429-453.

https://doi.org/10.5840/beq200515329

Mosca, F., \& Civera, C. (2017). Digital Channels And Social Media Management in Luxury Markets.Routledge

Mosca, F., Casalegno, C., Civera, C. (2016). "Opportunities and Peculiarities of the Online for Communicating Corporate Social Responsibility. A cross investigation on luxury players and consumers' perceptions". British Academy of Management, Book of Proceedings, 1-26

Mosca F., Tamborrini P., Casalegno C. (2015), From Corporate Social Responsibility to Systemic Design: How to Compete by Leveraging the Value System", Symphonya, Emerging Issues in Management (symphonya.unimib.it), 2, 42-56.

http://dx.doi.org/10.4468/2015.2.04mosca.tamborrini.casalegno

Muirhead S.A. (1999), “Corporate Contributions: the View from 50 Years”, New York: The Conference Board

Murray, A. (2005). “The economy, business: Will 'social responsibility' harm business?”, The Wall 
Street Journal, May 18.

O'riordan, L., \& Fairbrass, J. (2008). Corporate social responsibility (CSR): Models and theories in stakeholder dialogue. Journal of Business Ethics, 83(4), 745-758.

https://doi.org/10.1007/s10551-008-9662-y

Perrini, F., \& Vurro, C. (2014). Stakeholder orientation and corporate reputation: A quantitative study on US companies. Symphonya. Emerging Issues in Management, 1, 53-65.

http://dx.doi.org/10.4468/2013.1.04perrini.vurro

Perrini F., Tencati A. (2008), Corporate Social Responsibility, Egea

Perrini F. (2005), "Building a European Portait of Corporate Social Responsibility Reporting", European Management Journal, 23(6), 611-627

Pfeffer, J., \& Salancik, G. R. (2003). The external control of organizations: A resource dependence perspective. Stanford University Press.

Pomering A., Dolnicar S. (2009), "Assessing the Prerequisite of Successful CSR Implementation: Are Consumers Aware of CSR Initiatives?”, Journal of Business Ethics, vol. 85, n. 2, pp. 285-301

Porter M., Kramer, R. (2002), “The Competitive Advantage of Corporate Philanthropy”, Harvard Business Review, vol. 80, n.12. pp. 57-68

Porter, M. E., \& Kramer, M. R. (2006). Strategy and society: the link between corporate social responsibility and competitive advantage. Harvard business review, 84(12), 78-92.

Post, J. E., Preston, L. E., \& Sauter-Sachs, S. (2002). Redefining the corporation: Stakeholder management and organizational wealth. Stanford University Press.

Rasche, A., \& Esser, D. E. (2006). From stakeholder management to stakeholder accountability. Journal of business ethics, 65(3), 251-267. https://doi.org/10.1007/s10551-005-5355-y

Risso, M. (2012). Exploring Partnerships for Social Innovation. Symphonya (symphonya.unimib.it), $2,26$. http://dx.doi.org/10.4468/2012.2.03risso

Rudolph, P. Letters to the Editor. (2005). "An Adam Smith Look at Green Regulations" The Wall street Journal, June 6.

Russell, C. A., Russell, D. W., \& Honea, H. (2016). Corporate Social Responsibility Failures: How do Consumers Respond to Corporate Violations of Implied Social Contracts?. Journal of Business Ethics,

136(4), 759-773.

https://doi.org/10.1007/s10551-015-2868-x

Salvioni D. M., Bosetti L. (2014) Sustainable Development and Corporate Communication in Global Markets, Symphonya. Emerging Issues in Management (symphonya.unimib.it), 1, 1-19. http://dx.doi.org/10.4468/2014.1.03salvioni.bosetti

Salvioni, D. M., \& Astori, R. (2013). Sustainable Development and Global Responsibility in Corporate Governance. Symphonya Emerging Issues in Management (symphonya.unimib.it), 1, 125.

http://dx.doi.org/10.4468/2013.1.03salvioni.astori

Sen S., Bhattacharya C.B. (2001), "Does Doing Good Always Lead to Doing Better? Consumer Reactions to Corporate Social Responsibility”, Journal of Marketing Research, 38, n.2, pp. 225-243 https://doi.org/10.1509/jmkr.38.2.225.18838

Sierra-García, L., Zorio-Grima, A., \& García-Benau, M. A. (2015). Stakeholder engagement, corporate social responsibility and integrated reporting: an exploratory study. Corporate Social Responsibility and Environmental Management, 22(5), 286-304. https://doi.org/10.1002/csr.1345 
Singh, J. (2016). The influence of CSR and ethical self-identity in consumer evaluation of cobrands. Journal of Business Ethics, 138(2), 311-326.

http://dx.doi.org/10.1007/s10551-015-2594-4

Smith S.R. (1997), "Partnerships, Community Building, and Local Government”, National Civic Review, 86, pp. 167-175

Soundararajan, V., Brown, J. A., \& Wicks, A. C. (2016, January). An Instrumental Perspective of Value Creation through Multi-stakeholder Initiatives. In Academy of Management

Proceedings(Vol. 2016, No. 1, p. 10598). Academy of Management. https://doi.org//doi:10.5465/AMBPP.2016.10598abstract

Strand, R., \& Freeman, R. E. (2015). Scandinavian cooperative advantage: The theory and practice of stakeholder engagement in Scandinavia. Journal of business ethics, 127(1), 65-85. https://doi.org/10.1007/s10551-013-1792-1

Surroca, J., Tribó, J. A., \& Zahra, S. A. (2013). Stakeholder pressure on MNEs and the transfer of socially irresponsible practices to subsidiaries. Academy of Management Journal, 56(2), 549-572. https://doi.org/10.5465/amj.2010.0962

Tanahashi K.T. (2010), “A Theoretical Profile of Globalisation and its Sustainability", International Journal of Sustainable Society, vol. 2, n.3

Taneja, S. S., Taneja, P. K., \& Gupta, R. K. (2011). Researches in corporate social responsibility: A review of shifting focus, paradigms, and methodologies. Journal of Business Ethics, 101(3), 343 364. https://doi.org/10.1007/s10551-010-0732-6

Visser, W., \& Kymal, C. (2015). Integrated value creation (IVC): beyond corporate social responsibility (CSR) and creating shared value (CSV). Journal of International Business Ethics, 8(1), 29.

Visser, W. (2012). The Future of CSR: Towards Transformative CSR, or CSR 2.0. Kaleidoscope Futures Paper Series, 1

Visser, W. (2010). The Evolution and Revolution of Corporate Social Responsibility. In Pohl, M., Tolhurst, N. Responsible Business: How to Manage a CSR Strategy Successfully, Wiley. https://doi.org//10.1002/9781119206156.ch21

Vitolla, F., Rubino, M., \&Garzoni, A. (2017). The integration of CSR into strategic management: a dynamic approach based on social management philosophy. Corporate Governance: The International Journal of Business in Society, 17(1), 89-116. https://doi.org/10.1108/CG-03-2016-0064

Vitolla, F., Rubino, M., \&Garzoni, A. (2016). Integrated corporate social responsibility: Driving factors and means of integration-a multiple case study analysis. Journal of Management Development, 35(10), 1323-1343. https://doi.org/10.1108/JMD-08-2015-0113

Waddock, S. A., Bodwell, C., \& Graves, S. B. (2002). Responsibility: The new business imperative. The Academy of Management Executive, 16(2), 132-148. https://doi.org/10.5465/AME.2002.7173581

Walsh, J. P., Weber, K., \& Margolis, J. D. (2003). Social issues and management: Our lost cause found. Journal of management, 29(6), 859-881. https://doi.org/10.1016/S0149-2063(03)00082-5

Yawar, S. A., \& Seuring, S. (2017). Management of social issues in supply chains: a literature review exploring social issues, actions and performance outcomes. Journal of Business Ethics, 141(3), 621 643. https://doi.org/10.1007/s10551-015-2719-9 